\title{
Dummy Load Device
}

National Cancer Institute

\section{Source}

National Cancer Institute. Dummy Load Device. NCI Thesaurus. Code C49933.

A simple electronic device used for testing purposes designed to draw the same current as a complex device. 